\title{
Reprezentace učiva: co vlastně vnímáme? ${ }^{1}$
}

\section{Content re-presentations: What we perceive?}

\author{
Tomáš Janko
}

\begin{abstract}
Abstrakt: Příspěvek se zabývá problematikou re-prezentace obsahu školního vzdělávání. V souvislosti $\mathrm{s}$ tím je představován koncept reprezentace učiva. Naznačovány jsou kognitivně psychologická východiska tohoto konceptu a jeho pedagogické, resp. didaktické souvislosti. Uvedena je typologie reprezentací, se kterými se žáci mohou setkat během školní výuky. Stručně jsou představovány také teorie sloužící k vysvětlování kognitivní architektury lidské mysli.
\end{abstract}

Klíčová slova: obsah vzdělávání, reprezentace obsahu, kognitivní architektura

\begin{abstract}
The contribution deals the with issue of educational content re-presentation. Psychological and educational aspects are described. In relation to theoretical background, typology of different modes of representations is suggested. Briefly described are theories of human cognitive architecture.
\end{abstract}

Keywords: educational content, modes of representation, cognitive architecture

\section{1 Úvod}

Př́ispěvek se zabývá problematikou re-prezentace obsahu školního vzdělávání. Téma spadá do oblasti psychologie učení. Souvisí zejména s problematikou transformace obsahu vzdělávání, ale dotýká se také evaluace učebnic.

Cílem příspěvku je představit teorii reprezentace, která poskytuje cenné informace, využitelné při evaluaci učebnic.

Médiem, které si udržuje významné postavení při prezentaci obsahu vzdělávání žákům je učebnice. Učebnicová tvorba zaživá opětovný rozmach a do struktury učebnic se dostávají nové „elementy”, které mají podporovat učení žáků. O tom jak tyto „elementy” fungují při zprostředkovávání obsahu vzdělávání, respektive do jaké míry podporují učení, toho však víme málo. Nedostatečně prozkoumáno je také, jak s těmito „elementy” v souvislosti s učením operují žáci.

Teorie reprezentace je jedním z konceptů sloužících k vysvětlování problematiky utváření znalostí. Zabývá se zkoumáním zákonitostí a principů, na jejichž základě dochází ke kognitivnímu zpracovávání vnějších podnětů různé modality a jejich následnému reprezentování $\mathrm{v}$ mysli jedince. V souvislosti s tím se pozornost zaměřuje zejména na zkoumání obsahu a struktury reprezentací. Zjišstováno je také, jak se reprezentace uplatňují při

\footnotetext{
${ }^{1}$ Př́íspěvek svým charakterem odpovídá tzv. working paperu. Jedná se o krátkou zprávu, která má za cíl stručně informovat o probíhajícím výzkumu. Smyslem je, mimo jiné, získání zpětné vazby týkající se řešeného výzkumného problému. Př́íspěvek vznikl v rámci řešení projektu MUNI/A/1020/2010 Nástroje pro monitoring a evaluaci kvality ve vzdělávání (NAME 2011). Jeho prezentace na konferenci byla podpořena Stipendijním fondem PdF MU.
} 
mentálních aktivitách jako je např. řešení problému, usuzování anebo učení (Eysenck \& Keane, 2008; Sedláková, 1992).

\section{Reprezentace učiva: vymezení problematiky}

Problematika utváření a re-prezentace poznatků v lidské mysli je velmi komplexní. Jedná se o téma, kterému je věnována pozornost ve více oborech lidského poznání (kognitivní psychologii, pedagogické psychologii, sociální psychologii ad.). Jednotlivé obory však na problematiku nahlížejí z různých úhlů.

$\mathrm{V}$ pedagogické psychologii je problematika reprezentace řešena zejména $\mathrm{v}$ souvislosti s problematikou psychodidaktické transformace obsahu vzdělávání. Uchopována je ale také v souvislosti s vysvětlováním procesů učení. Poznatky vyplývající ze zkoumání problematiky reprezentace jsou však ,využitelné” i v rámci evaluace učebnic.

Výzkumná pozornost se zaměřuje na reprezentace učiva (Janík, Maňák, \& Knecht, 2009, s. 110-120), jež představují specifické nástroje, které učitel využívá k prezentování, vysvětlování anebo objasňování fenoménů, pocházejících z různých oblastí lidského poznání, během výuky (srov. Janík et al., 2009, s. 111). Jde zejména o zkoumání toho, jaké charakteristiky by reprezentace učiva měly vykazovat (resp. jakým zpo̊sobem by měly transformovat obsah vzdělávání), aby podporovaly učení žáků. Předmětem zkoumání jsou také zákonitosti vytváření a používání reprezentací učiva ve výuce.

\section{Reprezentace učiva: nástroje podporující učení?}

\subsection{Reprezentace učiva a učení}

Ukazuje se, že $\mathrm{v}$ souvislosti $\mathrm{s}$ učením fungují reprezentace zejména jako prostředek vyvolávající socio-kognitivní konflikt a podporující konceptuální změnu (Waldmann, 2006; Hardyová et al., 2004; Klausmeier, 1976 ad.). Výzkumy problematiky nicméně dokumentují, že reprezentace fungují jako prostředek konceptuální změny pouze za určitých okolností. Reprezentace jako prostř̌edek konceptuální změny mohou být úspěšné tehdy, pokud je žák nespokojen se svými dosavadními koncepty a pokud reprezentace nabízejí alternativní koncepty, které se žákovi jeví jako smysluplnější, a kterým rozumí (Posner et al., 1982).

\subsection{Reprezentace učiva a učebnice}

Didaktickým prostředkem, ve kterém se žáci s reprezentacemi učiva setkávají především je učebnice. Reprezentace učiva tak za určitých okolností mohou sloužit jako indikátor při posuzování didaktické vybavenosti a edukační potenciality učebnic.

Janík (2006, s. 33-44), k výše uvedenému dodává, že je nutné reflektovat zejména to, do jaké míry reprezentace při re-prezentování učiva balancují mezi ohledem na možnosti žákova porozumění a ohledem na správnost didaktického ztvárnění určitého obsahu vůči oboru. Zohledňováno by však mělo být také to, zda reprezentace při prezentování obsahu inklinují spíše k přirozenému jazyku žáka nebo odbornému jazyku experta. Důležité je také to, do jaké míry reprezentace „odrážejí” zásady konstruktivistického př́ístupu k učení. 


\section{Typologie reprezentací učiva}

Typologii reprezentací učiva nabízejí např. Janík et al. (2009, s. 113-120). Uvedení autoři na základě výzkumů zabývajících se problematikou reprezentace a učení rozlišují následující formy reprezentací:

Jednoduché vs. vícenásobné - učivo je možné žákům prezentovat prostřednictvím ,jednoduchých” reprezentací, které působí na jeden smyslový kanál. Výzkumy však naznačují (Ainsworthová, 2006; Kozma, 2003 ad.), že je efektivnější učivo prezentovat prostřednictvím vícenásobných reprezentací, které působí na více smyslových kanálů. Žáci však operují s různými formami reprezentace různě, což může mít vliv na učení $\mathrm{z}$ vícenásobných reprezentací.

Žákovi blizké vs. žákovi vzdálené - žákovi blízké reprezentace jsou vázány na kontext jeho dosavadních zkušeností. Žákovi vzdálené reprezentace jsou vázány na kontext oboru (Janík et al., 2009, s. 115). Srozumitelnost reprezentace pro žáka a její „propojitelnost” s dosavadními zkušenostmi je důležitým aspektem reprezentace v kontextu učení.

Předkládané učitelem vs. konstruované žáky - reprezentace předkládané učitelem představují kulturně etablované způsoby reprezentování určitých fenoménů. Naproti tomu reprezentace konstruované žáky představují výsledek subjektivní „interpretace” určitých fenoménů. Z hlediska učení se jako žádoucí jeví konfrontovat reprezentace konstruované žáky s reprezentacemi předkládanými učitelem.

Experimentální, vizuální, verbální - při rozlišování těchto forem reprezentací je zohledňováno na jaký smyslový kanál při re-prezentaci fenoménů působí a to jakou roli hrají při výukových aktivitách. Do hry se zde dostává také problematika učebních stylů žáků.

Níže uvedené schéma zjednodušeně znázorňuje fungování reprezentací učiva (v tomto př́padě vizuálních) jako prostředku vyvolávajícího socio-kognitivní konflikt, který může vyústit až v přehodnocení stávajících konceptů žáka, konceptuální změnu.

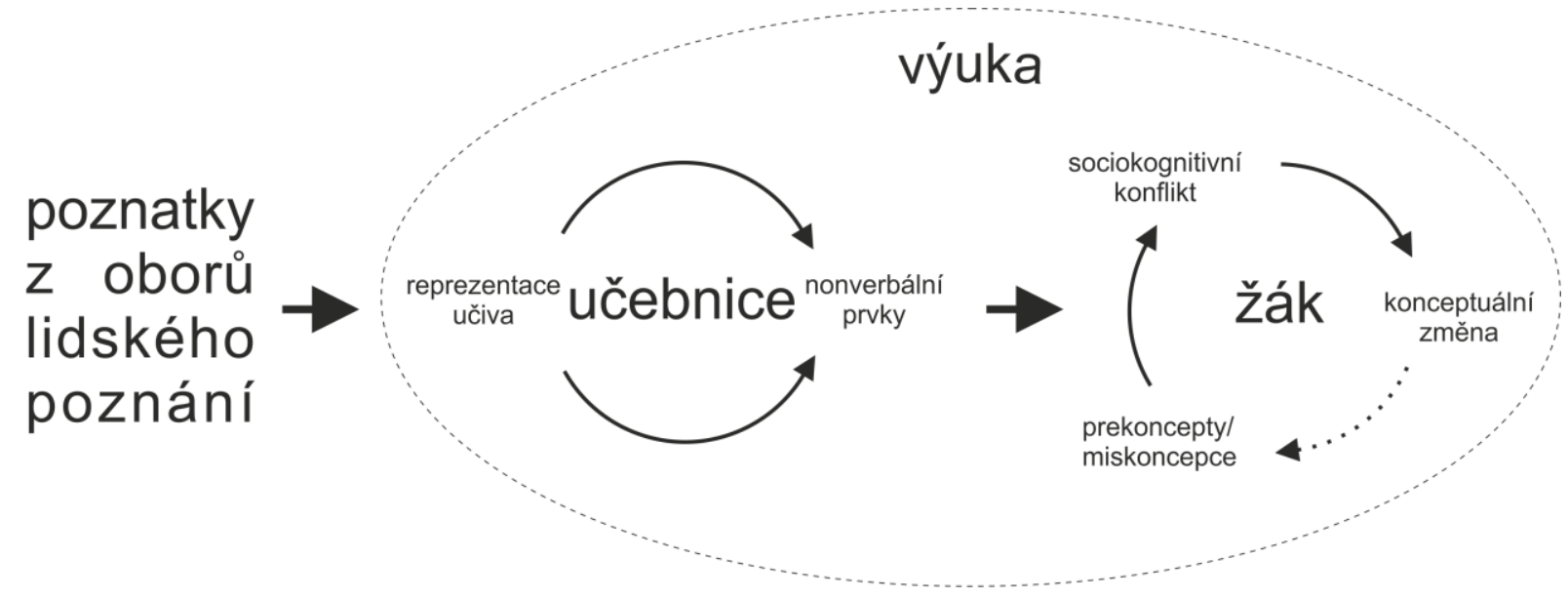

Obrázek 1. Schéma znázorňující fungování reprezentací jako prostředku podporujícího konceptuální změnu. 
Důležitým aspektem problematiky je otázka kognitivního zpracovávání reprezentací učiva. Představu o tom, jak dochází ke kognitivnímu zpracovávání reprezentací učiva si lze vytvořit na základě studií, které se zabývají se problematikou kognitivního zpracovávání podnětů různé modality.

Mareš (1995, s. 320-321) v souvislosti se zpracováváním obrazových informací (učením z obrazového materiálu) rozlišuje model duálního kódování, model unárního kódování a senzoricko sémantický model (viz obr. 2).
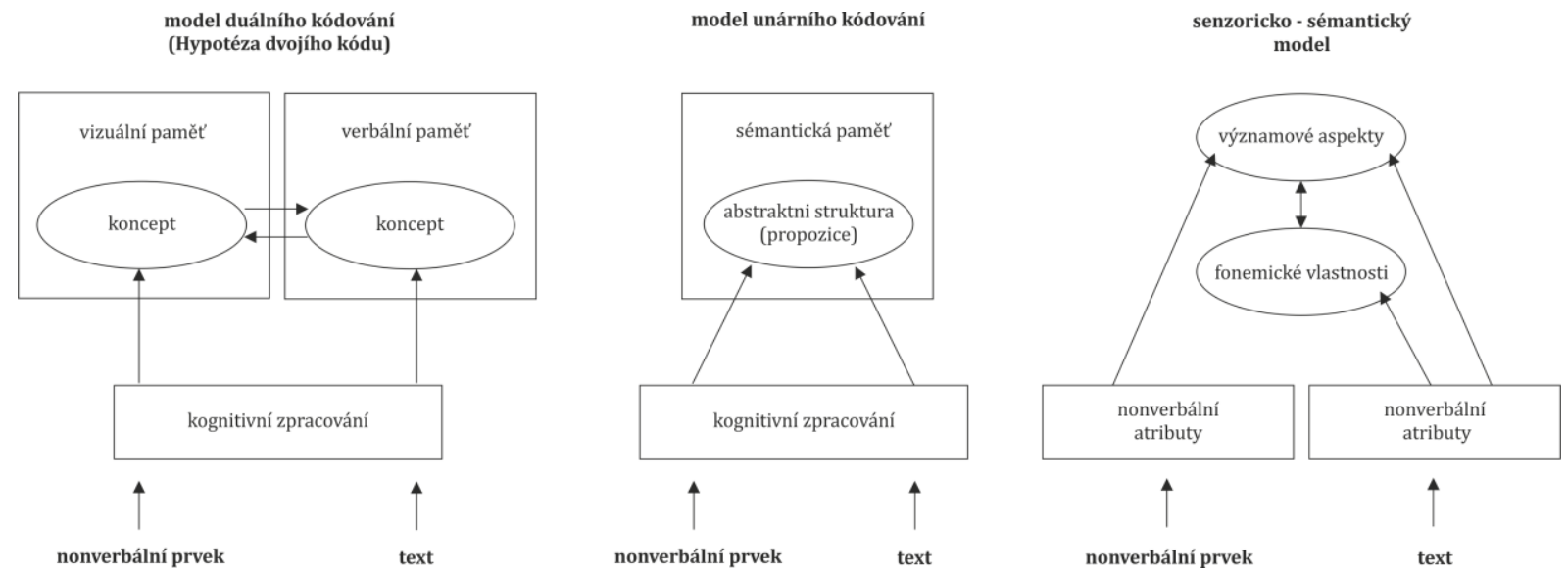

Obrázek 2. Model duálního kódování, model unárního kódování, senzoricko-sémantický model (upraveno dle Mareš, 1995, s. 320-321).

Problematikou kognitivního zpracovávání reprezentací se zabývá také Reed (2006), který shrnuje poznatky vyplývající z koncepcí následujících autorů: Paivio (Dual Coding Theory), Baddeley (Working MemoryModel), Engelkamp (Multimodal Theory), Sweller (Cognitive Load Theory), Mayer (Multimedia design priciples), Nathan (Constructivist Feedback). Reed (2006, s. 96) konstatuje, že v souvislosti se zkoumáním problematiky reprezentací a učení zůstává řada nezodpovězených otázek. Ty se týkají zejména kognitivního operování $\mathrm{s}$ vícenásobnými reprezentacemi.

\section{Literatura}

Ainswoth, S. (2006). DeFT: A conceptual framework for considering learning with multiple representations. Learning and Instruction, 16(3), 183-198.

Eysenck, M. W., \& Keane, M. T. (2008). Kognitivni psychologie. Praha: Academia.

Hardy, I., Jonen, A., Miller, K., \& Stern, E. (2004). Die integration von repräsentationsformen in den sachunterricht der grundschule. In J. Doll, \& M. Prenzel (Hg.). Bildungsqualität von schule. lehrerprofessionalisierung, unterrichtsentwicklung und schülerförderung als strategien der qualitätsverbesserung (pp. 267-283). Münster: Waxmann.

Janík, T. (2006). Teorie konceptuální změny a učebnice. In J. Maňák \& D. Klapko (Ed.), Učebnice pod lupou (pp. 33-44). Brno: Paido.

Janík, T., Maňák, J., \& Knecht, P. (2009). Cíle a obsahy školního vzdělávání a metodologie jejich utvárení. Brno: Paido.

Klausmeier, H. J. (1976). Instructional design and the teaching of concepts. In J. R. Levin, \& V. R. Allen, Cognitive learning in children. Theories and strategies (pp. 191-215). New York, San Francisco, London: Academic Press. 
Kozma, R. (2003). Supporting coherence formation in learning from multiple representations. Learning and Instruction, 13(2), 205-226.

Mareš, J. (1995). Učení z obrazového materiálu. Pedagogika, 45(4), 318-237.

Posner, G. J., Strike, K. A., Hewson, P. W., \& Gertzog, W. A. (1982). Accommodation of a scientific conception: Towards a theory of conceptual change. Science Education, 66(4), 221-227.

Reed, S. K. (2006). Cognitive architectures for multimedia learning. Educational Psychologist, 41(2), 87-98.

Sedláková, M. (1992). Př́spěvek k analýze pojmu mentální reprezentace v soudobé psychologické teorii. Československá psychologie, 36(4), 289-308.

Sedláková, M. (2004). Vybrané kapitoly z kognitivní psychologie. Mentální reprezentace a mentální modely. Praha: Grada.

Waldmann, M. R. (2006). Konzepte und Kategorien. In J. Funke \& P. A. Frensch (Hrsg.). Handbuch der allgemeinen Psychologie. Kognition (pp. 283-293). Göttingen: Hogrefe.

\section{Kontakt}

Mgr. Tomáš Janko

Institut výzkumu školního vzdělávání PdF MU

Pedagogická fakulta MU

Pořičí 31, 60300 Brno

e-mail: tjanko83@gmail.com

\section{Bibliografické údaje}

Janko, T. (2011). Reprezentace učiva: co vlastně vnímáme? In T. Janík, P. Knecht, \& S. Šebestová (Eds.), Smišsený design v pedagogickém výzkumu: Sborník př́spěvků z 19. výroční konference České asociace pedagogického výzkumu (s. 238-242). Brno: Masarykova univerzita.

Dostupné z: http://www.ped.muni.cz/capv2011/sbornikprispevku/janko.pdf

doi: 10.5817/PdF.P210-CAPV-2012-16 